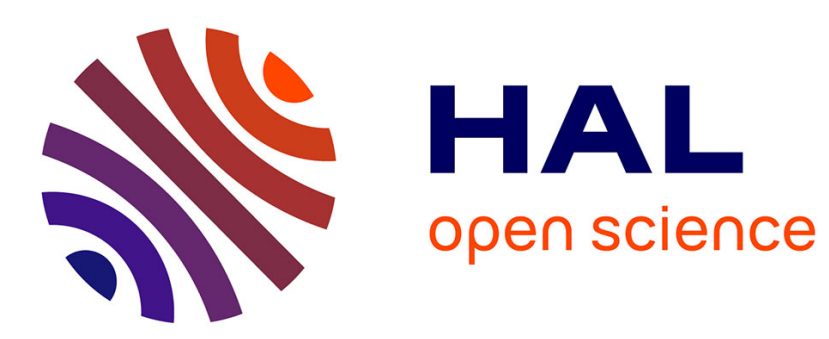

\title{
The Europeanization of Public Discourse in Italy
}

Donatella Della Porta, Manuela Caiani

\section{To cite this version:}

Donatella Della Porta, Manuela Caiani. The Europeanization of Public Discourse in Italy. European Union Politics, 2006, 7 (1), pp.77-112. 10.1177/1465116506060913 . hal-00571722

\section{HAL Id: hal-00571722 \\ https://hal.science/hal-00571722}

Submitted on 1 Mar 2011

HAL is a multi-disciplinary open access archive for the deposit and dissemination of scientific research documents, whether they are published or not. The documents may come from teaching and research institutions in France or abroad, or from public or private research centers.
L'archive ouverte pluridisciplinaire HAL, est destinée au dépôt et à la diffusion de documents scientifiques de niveau recherche, publiés ou non, émanant des établissements d'enseignement et de recherche français ou étrangers, des laboratoires publics ou privés. 


\section{EUP}

European Union Politics

DOI: $10.1177 / 1465116506060913$

Volume 7 (1): 77-112

Copyright@ 2006

SAGE Publications

London, Thousand Oaks CA

New Delhi

\section{KEY WORDS}

- Europeanization

- frames

- mass media

- public discourse

- social movements

\section{The Europeanization of Public} Discourse in Italy

\section{A Top-Down Process?}

\section{Donatella della Porta}

European University Institute, Florence, Italy

\section{Manuela Caiani}

University of Florence, Italy

\section{ABSTRACT}

European integration has raised hopes and concerns about its effect on the distribution of power among different actors, and in particular on the role of the civil society. Focusing on the Europeanization of public discourse in Italy as a case study, this article addresses the specific problem of the formation of supranational public spheres. On the basis of content analyses of daily press and interviews, we argue that various forms of Europeanization of the public discourse are indeed on the rise, with a growing presence not only of purely European actors but also of European targets and frames. Europeanization appears to have been traditionally a 'top-down' process: in fact the more Europeanized is a policy, actor, target or issue scope, the less civil society actors seem to have access to the public sphere. However, some changes across time emerge, with the development of (conflictual) forms of 'Europeanization from below'. 


\section{The Europeanization of public discourse: An introduction}

The growing competences of the European Union (EU) challenge parties, interest groups, and social movement organizations that have mainly developed at the national level. The European integration processes created hopes and fears concerning the distribution of resources and power between collective actors (Bartolini, 2002). Many studies have addressed the capacity of the traditional actors of representative democracies to adapt to, or even to take advantage of, European integration, focusing especially on their ability to organize and act at the European level (for the most recent contributions see Gabel and Hix, 2004; Steenbergen and Scott, 2004; Thomassen et al., 2004; Wessels, 2004).

In this article, we want to address the issue of the impact of Europeanization on national actors by focusing on their public discourse on European issues. We consider the public discourse on Europe as a relevant issue in normative as well as empirical terms. The accountability problem of international governmental organizations (IGOs) has usually been analysed in terms of a lack (or a weakness, in the case of the EU) of those traditional mechanisms of control developed in representative democracies: the 'democratic deficit' has indeed been mainly discussed in terms of the absence (or limited competences) of elected bodies. Democracies, however, require not only electoral bodies but also open arenas where public decisions are subject to the 'proof of discussion' (Manin, 1995). In democratic deliberation, issues referring to the public good are debated in public spheres of different types, including the mass media (Habermas, 1981, 1991): free and equal individuals hold governors accountable by engaging in discussions based on reason and the public good.

A central problem connected to the shift of power to supranational institutions is the difficulty of subjecting their decisions to the 'proof of discussion'. Some analyses have in fact linked the weak legitimacy of European institutions to the weakness of the European public sphere as a precondition for deliberative legitimization as well as representative accountability. The Europeanization of the public sphere has usually been considered a delicate issue, in terms of both the flimsiness of the process (Gerhards, 1993) and the lack of research on the topic (Le Torrec et al., 2001). Exploring this issue further, a number of characteristics of EU politics have been held responsible for the absence of a truly European public sphere: the democratic deficit linked to the limited powers of the European Parliament; the secretive working methods of the European Commission; and the intergovernmental nature of the European Council. Characteristics of the EU's media system have also been mentioned when explaining the low level of Europeanization 
in political communication, for instance the tendency of journalists to use traditional categories rather than describing the novel aspects of the European enterprise; the lack of a common language and a unified public; the prevalence of national agendas even in relation to purely EU news; and the prevalence of intergovernmental and elite-driven images of the EU (the European Commission, for example, appearing far more frequently than the Parliament) (Gerhards, 1993; Le Torrec et al., 2001).

The (largely pessimistic) body of research on the European public sphere mainly compares the latter with the forms and institutions of national public spheres, and assesses the difficulties encountered in the emerging European mass media, political parties, etc. In our work, we do not exclude the possibility of the formation of genuine, supranational European public spheres, yet we do speculate about the presence of different paths towards the Europeanization of a specific element related to the debate on the public sphere public discourse, defined as 'the "texts" emanating from the interaction of people in public debate' (Van de Steeg, 2002: 502), focusing our attention on media texts.

We use the concept of Europeanization to refer not only to 'the emergence and development at the European level of distinct structures of governance' (Risse et al., 2001: 3) but also to the impacts of these structures at the domestic level in influencing the ways in which collective actors make their demands visible in public discourses. In this sense, we address the 'processual' aspects of Europeanization (Fabbrini, 2003) by analysing the reciprocal influences activated between the European and national structures - what Radaelli and Franchino have recently defined as 'bottom-up Europeanisation' - to indicate a research design that is pitched at the level of domestic politics and policy (national or local): it starts from 'an analysis of the system of interaction (actors, resources, problems, style, and collective problem-solving rules) at the domestic level', and raises the question of 'whether the EU affects this system of interaction and if so in what way (as a resource, as a reformulation of the problem, as a new set of collective problem-solving rules, as a constraint on what is feasible, as an alteration to the opportunity structure, as a new frame of reference, etc.)' (Radaelli and Franchino, 2004: 948). We also focus on domestic actors, looking at the ways in which European institutions and European issues are discussed in public discourse.

In particular, an analysis of public discourse allows us to address 'soft pressures' on European integration, expressed through the alteration of the beliefs and expectations of national actors (Knill and Lehmkuhl, 1999). The way in which Europe is framed by different actors, together with the role of discourses and ideas, public debates, and political communication on Europe, is in fact gaining attention in social science research on Europeanization. If 
traditional theories that see European integration as driven by national economic interests provided little space for the role of national debates on European issues, the emergence of constructivist theories in international relations, as well as institutional analyses of Europeanization, has led to increasing attention being paid to the ways in which national actors perceive and define the process of Europeanization. Since the mid-1990s, there has been a social constructivist turn in research on Europeanization, a turn developed in order to study the impact of ideas and other socially constructed elements on several policy areas (Quaglia, 2004: 1097). In particular, Europeanization proceeds through the work of norms entrepreneurs that adopt and adapt European frames (see, for instance, Börzel and Risse, 2000), and Europeanization has an impact on the political discourses and ideas through which national actors define and justify their choices: 'Not only can Europe affect formal structures, it can also influence the values, norms and discourse prevalent in member states. In turn, cognitive transformation may change the preferences of policy-makers and therefore feedback into the process of European integration' (Radaelli, 2000: 2; see also Schmidt and Radaelli, 2004: 184). We will indeed analyse how Europe is framed in the public discourse.

In this sense, Europeanization is measured not only by the active presence of European actors but also by domestic actors' references to European institutions and issues. If Europeanization produces multi-level governance, then collective actions should adapt to intervening in and influencing the multiple territorial layers of governance. As we shall see, domestic collective actors do in fact seem to have adapted their action strategies so as not only to communicate with the various territorial levels of government but also to develop strategies of 'crossed influence'. That is, they attempt to apply pressure at the national level in order to change decisions at the European level, or conversely to apply pressure at the European level in order to change national decisions. A typology of the different forms of Europeanization of the public discourse can be built by combining the territorial scope of the claimant with that of the target. In a fully supranational polity, all important claims would be made by European political parties, interest groups, social movements and other collective actors targeting the European institutions, or, as Imig and Tarrow (2001b: 16) put it, 'with functional interests mobilised through European lobbies, territorial representatives organised in the EU Parliament, and state interests represented in the European Council'. National public discourses may, however, themselves Europeanize. This may, for instance, occur when European actors exercise transnational pressure by intervening in national public discourses, criticizing national policies or propagating European integration. A third path to the Europeanization of the public discourse is domestication, where debate over EU decisions takes place at the national level 
(Imig and Tarrow, 2001a). Domesticated claims are examples of claimsmaking in which the EU or its policies are either the source or the indirect target of claims by domestic actors, but where the direct target remains the nation-state. In their analysis of protest in Europe, Imig and Tarrow (2001a) stressed that most of the EU-related events that they singled out (406 out of 490) were cases of domestication, with an increase in all protest events from about $5 \%$ in 1992 to $10 \%$ in 1997 . Such mobilizations may be considered as proof of the dominant position of the nation-state. However, a more careful look shows the emergence, in the course of these campaigns, of innovations both in the organizational structure and in the frames of the protests (della Porta 2003a, 2003b). Finally, a form of externalization is present if and when the mobilizations and communications of national actors target the EU directly: this often takes place in an attempt to put pressure on the groups' own governments (Chabanet, 2002).

Where the degree of Europeanization of public discourse proves to be more relevant than expected, an important question is: who in the discursive arena gains from this shift in the territorial level of debate? Amongst those who stress the relevance of the process of European integration for national collective action, positions diverge on its effects in terms of the empowerment of different actors and coalitions. Some scholars expect that civil society actors, owing amongst other qualities to the flexibility of their organizational structures, will be able to adapt quickly to these changes (the increasingly mentioned concept of 'global civil society' testifying to this expectation). Others, however, are sceptical - not only that actors endowed with scarce material resources will be able to invest in transnational organizationbuilding and the staging of supranational protest events, but also that they can influence European politics 'from below' (della Porta and Tarrow, 2004). European integration has had the predictable effect of multiplying both restrictions and opportunities for various actors. Indeed, the construction of community institutions, as well as the policies developed by the EU, is increasingly the object of lively criticisms by loose networks of local, national and transnational actors. As Hooghe and Marks (1995), among others, have predicted, European integration no longer takes place under technocratic cover; there is, instead, an explicit and continuous political conflict between coalitions of governments, supranational bodies and national interests.

In particular, this article investigates the degree and forms of participation of various actors (institutional and non-institutional) in the Europeanization of public discourse - that is, their capacity to take part in the debates and mobilizations referring to European issues, targets and actors. We will also focus on the evaluation of the process of European integration by institutional actors, political parties, interest groups and social movement 
organizations, demonstrating that (different types of) actors are not merely adapting to the transforming political context but also bearing specific visions of 'what' Europe is and should be. In fact, qualitative information from interviews with representatives of several collective actors in Italy will indicate that support (or criticism) of European integration can be presented within extremely varied conceptions of Europe, which emerges in fact as an 'imagined community' that means very different things to different collective actors (della Porta and Caiani, 2005).

In what follows we shall describe the significant and growing degree of Europeanization apparent in Italian public discourse (see also Trenz and Eder 2004), albeit with a low presence of civil society actors. Our data indicate that, the more Europeanized a policy, actor, target or issue, the less civil society actors seem to have access to public discourse (at least in the mainstream media). However, we observe some changes across time that display a slowly emerging Europeanization from below. We shall, moreover, discuss the more conflictual attitudes of some civil society actors toward Europeanization.

\section{The Europeanization of public discourse: A research project}

The first aim of this article is to assess and compare the degree and forms of the Europeanization of public discourse. Thus, we investigate the extent to which collective actors operating within (national) Italian public discourse are carriers of Europeanization, by either organizing at the European level, making demands on European institutions, or framing their demands within European frameworks. Mainly using printed media as a data source, we analyse the general features of political claims-making by various types of actors, contrasting institutional and non-institutional actors - the latter often being indicated by the (widely understood) category of 'civil society actors'.

Focusing on the part of the public discourse represented in the printed media does not imply that this is considered to be the only arena in which claims are presented. In particular, some actors are less dependent upon the mass media because they enjoy direct access to decision-makers; others are less able to influence the mass media and therefore need to resort to alternative communication channels. Some may choose to address public opinion because their claims resonate with the majority public opinion; others may opt for less visible channels because they have more support among the elite than in the wider population. However, we assume that the printed media are one of the most important arenas of public claims-making, and that most actors will, at one stage or another, use them in order to make their views public. 
We shall analyse the presence of different types of Europeanization in Italy, in a cross-time $(1990,1995,2000,2002)$ and cross-issue perspective (in particular, besides the issue of European integration itself, we focus on six substantive policy fields, chosen strategically in that they present varying degrees of EU policy-making power). Our main assumption is indeed that the degree and forms of Europeanization of the public discourse of different actors will be influenced primarily by the political opportunities available for them - i.e. by the set of opportunities and constraints that are offered by the institutional structure and political culture of the political system in which they operate (see e.g. Tarrow, 1994). In a system of multi-level governance, we hypothesize a higher proportion of references to the European political institutions and discourses in those policy fields, such as agriculture and monetary policies, that fall under the first pillar, where EU competences are strongest; an intermediate level of Europeanization in policy areas such as migration and defence, which, although based on national decision-making, are discussed in intergovernmental forums (such as the Council of Ministers); and the least Europeanization on education and pension policies, which are affected by EU institutions through the less intrusive instrument of the Open Method of Coordination. Likewise, we hypothesize a growth of references to the European political institutions and discourses over time as the European integration process has deepened over the past 15 years.

Nevertheless, since the capacity to refer to the EU level is also related to the characteristics of actors, including their material and symbolic resources, we also expect important differences among collective actors within policy areas. The process of European integration being mainly carried out by government representatives and strengthening executive power at the national level (Moravcsik, 1994), we also hypothesize a larger presence of institutional actors in Europeanized debate. However, as the neo-functional approach to European integration has suggested, growing European competences tend to spill over into growing contention on European issues. We therefore also hypothesize that strategically oriented actors will increasingly address territorial levels with growing competences. Taking into account symbolic resources as well, we expect that targeting the EU level will help to spread supranational frames and identities, legitimizing European institutions even by contesting them.

Although the larger project of which this article is part includes seven European countries, here we will draw only on data for the Italian case, although we often compare these with the general trends in claims-making that has emerged in the other European countries in order to underline similarities and differences (based upon data available on the Europub.com website). ${ }^{1}$ In general, Italy has been considered to be a particularly Europhile 
country, with citizens (as in other southern European countries) holding low opinions of their national elites and being more confident instead in the functioning of European institutions (Sánchez-Cuenca, 2000). Faced with corruption and inefficient public administration, public opinion as well as political elites support European integration, which is perceived as an opportunity to 'normalize' the many Italian pathologies (Giuliani, 2000; Ferrera, 2003: 243). In opinion polls, Italian scores on net support for membership in the European Union were in line with the European average of $49 \%$ in 2000 ; this was well below not only Luxembourg (75\%) and Ireland (71\%), but also the Netherlands (64\%), Belgium and other southern European countries (all above 50\%); however, it was above West Germany (36\%), Denmark (29\%), the UK (5\%) and Sweden (1\%) (Diez Medrano, 2003: 10). Generous allocations of cohesion funds may have increased the traditional support for Europe that made Italy one of the founding fathers of the first European institutions. A southern European (less developed) welfare state has been cited as explaining high individual support for European integration (Sánchez-Cuenca, 2000; Brinegar and Jolly, 2005).

Bipartisan consensus on Europe was, however, challenged when the corruption scandals of the early 1990s ended in the disappearance of the Christian Democratic party and the emergence of the centre-right parties Lega Nord and Forza Italia, both of which are much less supportive of the European project. Qualitative research on the 'framing of Europe' yields frequent references to the benefits of common membership in terms of wellbeing and economic growth, as well as a belief in the advantages of joining forces with several small states, but also fears that the EU is opaque, distant, unaccountable and inefficient (Diez Medrano, 2003: Ch. 2). The enlargement of the European Union on its eastern borders, as well as the introduction of the euro and the austerity policy imposed in order to meet the Maastricht criteria for entering the European Monetary Union, have however contributed to breaking the permissive consensus around European integration. Most of the trends that we shall mention in this article are shared across nations, and the Italian case can be taken as an illustration of more general dynamics.

For the empirical data collection we use the methodology of political claim analysis (see Koopmans and Statham, 1999, 2002), a quantitative method that takes individual political claims as units of analysis and uses newspapers as a source for the publicly visible part of this claims-making. A claim is defined as an instance of strategic action in the mass media. It consists of the expression of a political opinion by physical or verbal action, regardless of the form this expression takes (statement, institutional decision, court ruling, protest, etc.), and regardless of the nature of the actor (media, governments, civil society actors, etc.). The claim analysis approach aims to integrate 
two methodological traditions of social movement research: (quantitative) protest event analysis (Tarrow, 1989; Franzosi, 1994) and (qualitative) frame analysis (Snow et al., 1986; Gamson and Modigliani, 1989). By systematically coding discursive dimensions, claim analysis broadens the scope of attention from protest to all forms of claims-making in the public domain, including conventional and verbal actions. Moreover, it locates social movement organizations within a larger multi-organizational field by including institutional and non-institutional actors. The main actors of claim analysis are no longer 'protesters' but claimants, namely the subjects of a strategic action (whether verbal or not) in the mass-mediated public discourse. Although the use of the daily press as a source of information on protest or public discourse has been criticized on the basis of the selection biases introduced by the rules of journalistic coverage, in our research this risk is limited since we are interested specifically in public claims-making. Further, in order to reduce the description bias (McCarthy et al., 1996), besides focusing on quality newspapers (which have to protect their reputation), we based our coding only on the factual coverage of events.

An act of claims-making can normally be broken down into the elements shown in Figure 1: subject actor, form, addressee, issue, object actor and frame (Koopmans and Erbe, 2002). In order to analyse degrees of Europeanization, we coded the polity/territorial scope at which each actor, addressee, object and frame are organized - distinguishing between local, regional, national, transnational (multilateral/bilateral), European and supranational (e.g. UN) actors.

Although our data set shows the claims-making of detailed categories of actors (e.g. Italian unions, the Italian green party, etc.), our analysis in this article will focus on the characteristics of the claims-making of general categories of actors. Simplifying somewhat, we shall compare institutional actors (government/executive, judiciary, police and internal security agencies, military, central banks and other state executive agencies) with noninstitutional actors (which we shall refer to under the broad category of civil society), including media and journalists, economic interest groups

\begin{tabular}{|l|l|l|l|l|l|}
\hline $\begin{array}{l}\text { Who? } \\
\text { (Subject } \\
\text { actor) }\end{array}$ & $\begin{array}{l}\text { How? } \\
\text { (Form) }\end{array}$ & $\begin{array}{l}\text { At whom? } \\
\text { (Addressee } \\
\text { or target) }\end{array}$ & $\begin{array}{l}\text { What? } \\
\text { (Issue) }\end{array}$ & $\begin{array}{l}\text { Forlagainst } \\
\text { whom? } \\
\text { (Object actor) }\end{array}$ & $\begin{array}{l}\text { Why? } \\
\text { (Frame) }\end{array}$ \\
\hline $\begin{array}{l}\text { Pro- } \\
\text { immigrants } \\
\text { associations }\end{array}$ & $\begin{array}{l}\text { engage in } \\
\text { a strike }\end{array}$ & $\begin{array}{l}\text { criticizing the } \\
\text { Italian } \\
\text { government }\end{array}$ & $\begin{array}{l}\text { for the } \\
\text { treatment of }\end{array}$ & $\begin{array}{l}\text { some asylum } \\
\text { seekers }\end{array}$ & $\begin{array}{l}\text { arguing that respect for } \\
\text { human rights is a core } \\
\text { value of the European } \\
\text { Union }\end{array}$ \\
\hline
\end{tabular}

Figure 1 Example of the 'typical' structure of a claim. 
(composed of employers' organizations and firms, farmers and agricultural organizations, economists and financial experts and other professional organizations and groups) and social movement organizations (composed of unions and students', peace, women's, immigrants', environmental, consumer, welfare organizations, etc.). Unions have been included in the category of social movements because first analyses showed that on several dimensions they had the same trends and characteristics as other social movement organizations. Farmers and agricultural organizations, however, display patterns similar to those of other economic interest groups. When members of political parties spoke as representatives of public bodies (parliaments, governments, etc.), we counted them as institutional actors; when they did not play this role, we included them in a subcategory of non-institutional actors, thereby respecting the formal characteristics of parties as voluntary associations (even if close to the state). Owing to the small number of claims made by members of parties that do not speak as representatives of public institutions, this choice does not affect the result of our analysis; moreover, in the article we will often analyse trends for specific categories of actors, thus indicating if specific trends for parties will emerge.

Our data were gathered from the news coverage of two quality national newspapers that differ in political affiliation: La Repubblica (left oriented) and Il Corriere della Sera (centre oriented). We coded the years 1990, 1995, 2000 and 2002. Articles relating to our six policy domains plus the topic of European integration were collected from two issues per week for 2000 and 2002, and from one issue per week for 1990 and 1995. For 2000, we also included two regional newspapers (La Nazione and Il Mattino), of which one issue was coded per week. The greater part of the database $(90 \%)$ is constituted by articles from the two quality dailies. Culture and sports sections, letters to the editor and supplements were excluded from the coding; articles in the regional and local sections (where present) were included only if referred to in the international/national news section of the paper. Data were coded on the basis of a standardized codebook (Koopmans, 2002). All articles in the news section and in the economic and business section of the newspapers were checked for relevant acts. Inter-coder reliability tests were undertaken on both the selection of articles and the coding and, in addition, coders participated in regular online discussions about difficult cases. ${ }^{2}$ In Italy, for 1990, 1995, 2000 and 2002, 1331 articles were coded for a total of 3541 claims. Among these, 957 claims were selected for a reduced sample that included only articles with a European dimension in either the claimant, the addressee, the issue or the object. The remaining 2584 claims were selected from a full sample (all articles). ${ }^{3}$

In the last section of the article, we refer to yet another part of the research in which, between July 2003 and April 2004, we conducted around 
60 semi-structured interviews with representatives of the Italian organizations that emerged as most important from the claim analysis in the fields of European integration, agriculture and immigration. Interview partners were selected according to two criteria. First, we referred to the results of the political claim analysis (the frequency of appearance) concerning these three issue fields. Then we integrated the lists of the most influential actors in the debate with our knowledge of the core actors active in the policy domain under study; we also consulted academic experts in each field for additional suggestions. The semi-structured questionnaire focused on changes in the communication and mobilization strategies of collective actors related to the process of European integration. Concerning the interview sample, in each of the three policy fields, five interview partners were identified from four categories of collective actor (government/administration, political parties, economic interest groups and social movement groups), to make a total of 20 interviewees in each policy field. Further details on the sampling of our interview partners and the questionnaire used are available on the project website (for a qualitative and detailed analysis of the interviews, see della Porta, 2004; della Porta and Caiani, 2004, 2005).

\section{The dominant Europeanization: From above}

An important criterion for the analysis of the public debates and actions concerning Europe is the extent to which different types of collective actor participate in them. Which actors are the carriers of the Europeanization of public discourse? Are they institutional actors, pushing Europeanization from above, or civil society actors, bringing about a Europeanization from below? Both the realist and functionalist standpoints perceive European development as an elite-driven, top-down process. Institutional actors, at all territorial levels, have been seen as the driving force behind policy-making (see Imig and Tarrow, 2001a). Important studies in the field emphasize institutionbuilding as a formal process involving formal actors. However, much research on the formation of nation-states reveals that, over and above constitutional input 'from above', the construction of these territorial entities involved the development of a common identity through participation 'from below'. Moreover, the development of a 'European citizenship' is a topic of increasing interest to both scholars and policy-makers.

By looking at the Europeanization of public discourse by policy domain, we can test the hypothesis that discursive references to the EU increase with EU competences. The hypothesis that Europeanization is facilitated by the availability of organizational resources is instead tested by comparing 
Table 1 Type of claimant by issue field: 1990, 1995, 2000, 2002 (\%)

\begin{tabular}{|c|c|c|c|c|c|c|c|c|}
\hline Issue field & Institutional & $\begin{array}{l}\text { Non- } \\
\text { institutional }\end{array}$ & Parties & $\begin{array}{l}\text { Interest } \\
\text { groups }\end{array}$ & $\begin{array}{l}\text { Social } \\
\text { movements }\end{array}$ & Media & Total & $N$ \\
\hline Agriculture & 54.4 & 45.6 & - & 26.6 & 19.0 & - & 100.0 & 79 \\
\hline Immigration & 62.5 & 37.5 & 20.9 & 3.8 & 11.8 & 0.9 & 100.0 & 339 \\
\hline Troops & 84.9 & 15.1 & 6.5 & 1.0 & 1.3 & 6.3 & 100.0 & 398 \\
\hline Education & 37.2 & 62.8 & 7.7 & 2.7 & 49.7 & 2.7 & 100.0 & 584 \\
\hline European integration & 77.4 & 22.6 & 10.8 & 1.3 & 5.0 & 5.5 & 100.0 & 380 \\
\hline All policies & 61.9 & 38.1 & 9.6 & 6.3 & 18.6 & 3.6 & 100.0 & 2584 \\
\hline
\end{tabular}

Notes: Based on full sample issues only. Issue fields are: monetary policies: currency and interest rate; agriculture: subsidies, quotas, disease control; immigration: entry and exit; troop deployment; retirement and pension schemes; education; European integration. Cramer $V$ between the variable actor type (social movements, economic interest groups, parties, media and state actors) and the variable issue field $=0.29 * * *(P \leq .001) ; C$ ramer's $V$ between actor type (civil society and state actors) and issue field $=0.36^{* * *}(P \leq .001)$. 
institutional and non-institutional actors. When looking at which types of actors make claims in public discourse according to the seven policy domains covered in our research (see Table 1), we notice a decline in the presence of civil society actors in those fields in which the European Union has more formal competences. In the fields of monetary policy and European integration, institutional actors monopolize the debate and civil society has a very low presence, with the partial exception of economic interest groups and parties. The range of actors involved in education and pension policies is more differentiated, with a significant presence of civil society organizations. Nevertheless, the correlation between the degree of institutionalization of EU competences and a weak presence of civil society does not hold for troop deployment (low EU competence combined with a low presence of civil society actors) and agriculture (relevant EU competences but a significant presence of civil society actors). In the debate on education, civil society actors are mainly constituted by nongovernmental organizations (NGOs) and social movements, whereas in the debate on pensions the range of civil society actors is more evenly distributed between parties, economic interest groups and social movements. In terms of Europeanization, the data indicate that, in the Italian public discourse, issues of European integration as well as those concerning monetary policy and troop deployment are strongly debated within the institutional arena, whereas discussions on pensions and education, but also the already Europeanized domain of agriculture, are more pluralistic, involving a wider range of actors.

When looking at claim-makers, it is worth noting that, among European and supranational/transnational actors, institutional actors account for the vast proportion (88-94\%). We find very few civil society actors organized at the EU level (6\%) and, where present, they more often represent institutionalized economic interest groups than public interest associations and NGOs. Surprisingly, non-EU supranational civil society actors, as well as forms of transnational linkages among civil society actors through multilateral contacts, are more present $(12 \%)$ than EU civil society actors. These findings indicate the constraints on the emergence of a transnational civil society that could stimulate European integration from below, or at least high thresholds for such organizations to appear in the public domain.

However, looking at the presence of European actors as claim-makers is only one way to investigate the Europeanization of public discourse. Another indicator of Europeanization, although of a different type, is the choice of European institutions as the targets of collective demands. Table 2 shows that, overall, although national (and subnational) actors are still the main focus of collective mobilization and debate (58.3\%), European actors and institutions nevertheless have a role to play (17.9\%). Even actors from other EU member states have some role as addressees of claims-making, whereas supranational 
Table 2 Scope of the target by actor type: Selected policy fields, 1990, 1995, 2000, 2002 (\%)

\begin{tabular}{|c|c|c|c|c|c|c|c|c|c|}
\hline Actor type & $\begin{array}{l}\text { Local/ } \\
\text { regional }\end{array}$ & $\begin{array}{l}\text { National } \\
\text { (Italy) }\end{array}$ & $\begin{array}{l}\text { National } \\
\text { (EU members) }\end{array}$ & $\begin{array}{l}\text { National } \\
\text { (non-EU) }\end{array}$ & Bi/multilateral & $E U$ & $\begin{array}{l}\text { Supranational } \\
\text { (non-EU) }\end{array}$ & Total & $N$ \\
\hline Institutional & 2.3 & 37.5 & 11.0 & 15.3 & 3.0 & 25.5 & 5.4 & 100.0 & 888 \\
\hline Non-institutional & 8.6 & 71.6 & 5.5 & 3.5 & 0.4 & 9.0 & 1.5 & 100.0 & 748 \\
\hline Parties & 4.4 & 81.2 & 5.0 & 1.0 & 1.0 & 7.5 & 0.0 & 100.0 & 201 \\
\hline Interest groups & 5.0 & 56.7 & 9.2 & 5.8 & 0.0 & 20.0 & 3.3 & 100.0 & 120 \\
\hline Movements & 12.9 & 74.9 & 3.4 & 3.1 & 0.3 & 4.4 & 1.0 & 100.0 & 385 \\
\hline Media & 0.0 & 38.1 & 16.7 & 11.9 & 0.0 & 26.2 & 7.1 & 100.0 & 42 \\
\hline All actors & 5.2 & 53.1 & 8.5 & 9.9 & 1.8 & 17.9 & 3.6 & 100.0 & 1636 \\
\hline
\end{tabular}

Notes: Based on full sample issues only. Cramer's $\vee$ between target scope and actor type (social movements, economic interest groups, parties, media and state actors) and the variable issue field $=0.23^{* * *}(P \leq .001)$; Cramer $\mathrm{V}$ between target scope and actor type (civil society and state actors) $=0.41^{* * *}(P \leq .001)$. 
and transnational (bilateral/multilateral) actors are rarely present. However, what is most striking in the comparison between types of actor is that civil society actors are significantly less likely to address their political demands to European and supranational institutions than are institutional actors. The exceptions here are economic interest groups and the media, which frequently direct their claims to European addressees; parties show similar tendencies to social movements.

A cross-policy comparison of the scope of the targets of different types of actor points to important differences. There is a strong presence of European addressees for both institutional and civil society actors on issues concerning European integration, monetary policy and agriculture. In contrast, little attention is paid to the EU as a target of claims-making on issues of immigration and even less so on issues concerning education and pensions. A fairly similar picture of low European targeting emerges in the policy field of troop deployment, although here civil society actors address their claims to European actors much more often than institutional actors do.

Another important indicator of the Europeanization of public discourse is the scope of the issues that are mobilized by claims. Issue scope refers to the geographical and/or political scope of the substantive content of the claim. The issue scope is in principle independent from the scope of the subject actor, target and/or object, referring instead to the framing of a demand. For instance, if Amnesty International appeals to the European Court of Justice in order to protest against the Milanese regulation that privileges Lombards whilst discriminating against immigrants, the actor is supranational, the addressee is European, but the scope of the issue remains local. However, if a local Milanese committee, acting in defence of migrants, criticizes the Milanese city council for their migration policy on the grounds that it constitutes a breach of the international conventions on human rights, then the issue scope is supranational, in spite of the local scope of the actor and addressee. This indicator allows us to investigate the 'salience' of the integration process in the everyday life of citizens: the question is whether the nationstate remains the primary focus for debates, discourses and the formation of collective identities, or whether, on the contrary, actors increasingly frame their claims within a European dimension. In order to avoid overestimating claims with a European dimension, in Table 3 and the following analyses related (cross-time and cross-issue), claims in the field of European integration are not included, since their scope is by definition European.

In claims made by institutional actors, issues are often framed with specific reference to Europe, whereas in claims made by non-institutional actors national references remain more important (see Table 3). However, the differences between the two types of actor in terms of the Europeanization of 
Table 3 Scope of issue by actor type: Selected policy fields, 1990, 1995, 2000, 2002 (\%)

\begin{tabular}{|c|c|c|c|c|c|c|c|c|c|}
\hline Actor type & $\begin{array}{l}\text { Local/ } \\
\text { regional }\end{array}$ & $\begin{array}{l}\text { National } \\
\text { (Italy) }\end{array}$ & $\begin{array}{l}\text { National } \\
\text { (EU members) }\end{array}$ & $\begin{array}{l}\text { National } \\
\text { (non-EU) }\end{array}$ & Bi/multilateral & $E U$ & $\begin{array}{l}\text { Supranational } \\
\text { (non-EU) }\end{array}$ & Total & $N$ \\
\hline Institutional & 3.2 & 33.4 & 4.1 & 3.5 & 18.1 & 22.9 & 14.8 & 100.0 & 1305 \\
\hline Non-institutional & 7.6 & 62.6 & 3.1 & 4.7 & 6.8 & 11.9 & 3.3 & 100.0 & 899 \\
\hline Parties & 4.8 & 67.7 & 2.9 & 0.0 & 12.6 & 9.2 & 2.9 & 100.0 & 207 \\
\hline Interest groups & 3.7 & 40.3 & 5.0 & 10.7 & 2.5 & 32.7 & 5.0 & 100.0 & 159 \\
\hline Movements & 11.2 & 72.8 & 2.4 & 4.5 & 3.0 & 5.0 & 1.1 & 100.0 & 462 \\
\hline Media & 1.4 & 3.1 & 4.2 & 5.6 & 23.9 & 18.3 & 15.5 & 100.0 & 71 \\
\hline All actors & 5.0 & 33.7 & 3.1 & 3.4 & 11.5 & 30.4 & 8.7 & 100.0 & 2204 \\
\hline
\end{tabular}

Notes: Based on full sample issues only. Cramer's $V$ between issue scope and actor type (social movements, economic interest groups, parties, media and state actors) and the variable issue field $=0.23^{* *}(P \leq .001)$; Cramer $\mathrm{V}$ between issue scope and actor type (civil society and state actors $)=0.35^{* * *}(P \leq .001)$. 
public discourse are slightly less evident than for the other previously mentioned indicators. Amongst non-institutional actors, reference to the European Union is very limited in instances of social movements' claimsmaking but is much more present in the claims of economic interest groups and the media.

Yet here, too, there are significant differences between the issue fields. Monetary policy and agriculture are often framed with specific reference to Europe $(64.0 \%$ of claims with a European issue scope made by institutional actors, and $56.8 \%$ of those made by non-institutional actors for monetary policy, and $44.2 \%$ and $30.6 \%$, respectively, for agriculture). In immigration, troop deployment, pensions and education, however, claims referring to the European Union are present at only a very low degree, especially in the claims made by non-institutional actors (4-9\% institutional actors, 2-3\% non-institutional). Unsurprisingly, for pensions and education - fields that remain under the full control of national political institutions - public debate is almost entirely concentrated within the Italian national space. ${ }^{4}$ Nevertheless, in these fields, especially that of pensions, a small but significant portion of claims (in the range of 7-9\% for both types of actor) refers to other EU members.

These results may be explained by the tradition of institutional, bipartisan support for European integration, as well as the weak structure of civil society actors, but the Europub.com research project confirmed similar trends in the other six countries covered (on the basis of as many as 20,000 political claims collected from 28 newspapers). Across all countries, debates on European integration (compared with those on the other issue fields) turn out to be highly elitist. State and party actors dominate every issue field, but nowhere as strongly as in the debates on European integration, where $81 \%$ of the speakers are state or party actors (70\% in the seven-issue average). Economic interest groups and other civil society groups are much less prominent in debates on European integration than in the other issue fields - respectively, $2 \%$ (against $10 \%$ on average for all seven issues) and $5 \%$ (against $11 \%$ for the seven-issue average) (Koopmans, 2004: 45).

\section{The slowly emerging Europeanization from below}

The Europeanization of public discourse seems, at first glance, to reduce the opportunities for non-institutional actors: Europeanization appears to be mainly imposed 'from above'. This is no surprise. Research on protest events, usually based on newspaper sources, stresses the scarcity of protests that directly target European institutions. Using Reuters World News Service and Reuters Textline, Imig and Tarrow (2001a) - the first to analyse protest at the 
EU level - found a very limited number of such protests. Similarly, in Germany, Rucht (2002) has observed a low (and declining) proportion of protests aimed at the international level (the highest levels being reached in 1960-4); he concludes that, 'as far as Germany is concerned, the Europeanization and, more in general, Europeanization of protest is a myth' (Rucht, 2002: 185). Meanwhile Giugni and Passy (2002) noted how rarely protests on migrants' rights target the EU, notwithstanding the increasing Europeanization of decisions on migration, at least in terms of access quotas and border controls. Even environmental action is very rarely aimed at Brussels: protests with EU targets ranged from $0.8 \%$ in Italy to $4.6 \%$ in Germany in the past decade, with no discernible increasing trend (Rootes, 2002).

Our data, however, point to a significant and slowly growing adaptation among non-institutional actors to the shift in competences and discourses to the supranational level. In terms of targets and issue scope, the presence of non-institutional actors has indeed been slowly increasing, although not in a linear fashion, over the years in Italy (see Figure 2). In particular, whereas claims with a national Italian issue scope have increased (although not in a linear manner) for institutional actors (from 20.3\% of claims in 1990 to $42.9 \%$ in 1995 to $47.4 \%$ in 2000 to $35.7 \%$ in 2002), they have decreased for non-institutional actors (from $71.6 \%$ in 1990 to $79.5 \%$ in 1995 to $65.8 \%$ in 2000 to $64 \%$ in 2002). Instead, it is the European level that has become more and more prominent over the years, especially for non-institutional actors, who have tripled these types of claim in more recent years (from $4.5 \%$ in 1990 to $17.3 \%$ in 2000 and $15 \%$ in 2002, compared with institutional actors with $14.4 \%$ in $1990,15.4 \%$ in $1995,23.1 \%$ in 2000 and $36.0 \%$ in 2002). Relatively little attention, decreasing across the years, is paid to other EU countries by both types of actor. Claims with an issue scope referring to other EU members represented a share of $5.9 \%$ and $3.4 \%$ for institutional and non-institutional actors in $1990,7.1 \%$ and $4.1 \%$ in $1995,3.8 \%$ and $2.5 \%$ in $2000,0.3 \%$ and $2.5 \%$ in 2002 . More precisely, in claims-making referring to Europe, economic interest groups, social movements and the media in particular have increased their presence over the years (economic interest groups from $11.1 \%$ of all claims in 1990 , to $18.2 \%$ in $1995,43.8 \%$ in 2000 and $42.4 \%$ in 2002 ; social movements from about $3-4 \%$ of all claims in 1990, 1995 and 2000 to $12.0 \%$ in 2002; the media from none in 1990, to $11.1 \%$ in $1995,53.8 \%$ in 2000 and $15.4 \%$ in 2002). ${ }^{5}$

The proportion of claims addressed to EU targets also increased significantly between 1990 and 2002 for non-institutional actors, and at a higher speed than for institutional actors. Whereas in 1990 and 1995 only the media, parties and economic interest groups addressed their claims to European institutions, from 2000 onwards even social movements began to address the European level; at the same time, other non-institutional actors were also 


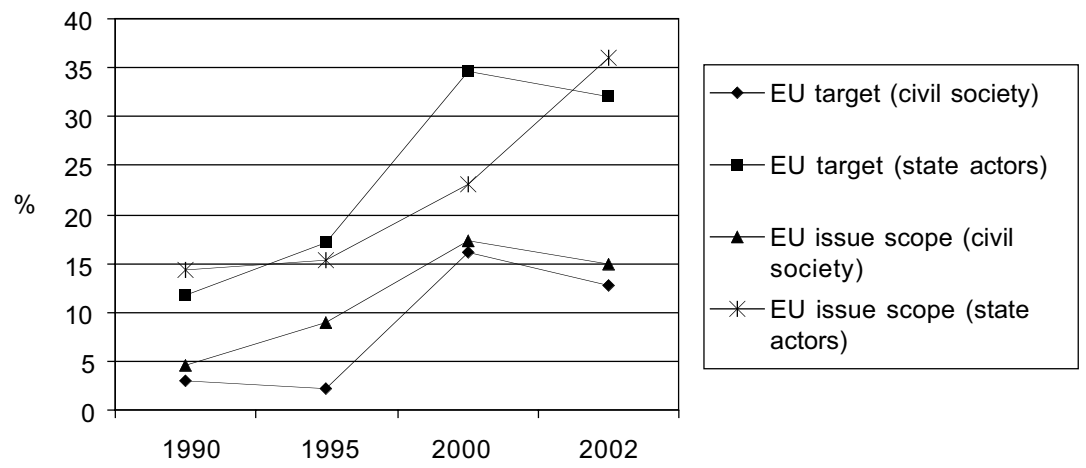

Figure 2 Share of claims with EU scope (issues and targets) across time, by actor type.

increasingly targeting the EU (e.g. 5.6\% of economic interest groups' claims had a European addressee in 1995, growing to about 25-28\% in 2000 and 2002). ${ }^{6}$

This growing 'Europeanization from below' does, however, follow a peculiar pattern. Applying our typology of forms of Europeanization to our data on claims-making in Italy (Table 4), ${ }^{7}$ we can see that, overall, the Europeanization of public discourse mainly assumes the forms of domestication $(34.6 \%)$ and externalization (31.3\%). Supranational dynamics are also relevant $(24.6 \%)$, but transnational pressure applies to only $9.5 \%$ of cases. However, a comparison of institutional and non-institutional actors points to important differences in the forms of Europeanization. Focusing on claims made by institutional actors, supranationalization and externalization are equally dominant forms of Europeanization (representing 30.0\% and 33.3\%, respectively); domestication is slightly less significant (26.9\%); and the intervention of EU institutional actors targeting a member state is less frequent (12.5\%), at least in the 'visible' public discourse. If we focus instead on non-institutional actors, we see that the prevailing type of Europeanization is domestication $(55.8 \%)$ but that externalization is also important $(33.3 \%)$; the presence of European social actors addressing either the EU (9.6\%) or national governments $(1.2 \%)$ is much less frequent, although not negligible. In more detail, parties are most often characterized by forms of domestication in claimsmaking with reference to Europe (70.0\% of all claims), whereas Europeanization via domestication covers about half of all claims among economic interest groups, social movements and the media $(46.5 \%, 53.4 \%$ and $42.4 \%$, respectively). Finally, economic interest groups and the media are the most involved in forms of supranationalization of public discourse (about $15 \%$ of all claims). 
Table 4 Forms of Europeanization of the public sphere by actor type (\%)

\begin{tabular}{|c|c|c|c|c|}
\hline \multirow{2}{*}{\multicolumn{2}{|c|}{ Scope of the claimant }} & \multicolumn{3}{|l|}{ Scope of the target } \\
\hline & & \multirow{2}{*}{$\begin{array}{l}\text { National } \\
\text { Domestication (1) }\end{array}$} & \multicolumn{2}{|l|}{$E U$} \\
\hline \multirow{4}{*}{ National } & Type of actor & & Externalization (2) & \\
\hline & Non-institutional & 55.8 & 33.3 & $N=249$ \\
\hline & Institutional & 26.9 & 30.6 & $N=687$ \\
\hline & All actors & 34.6 & 31.3 & $N=936$ \\
\hline \multirow{4}{*}{ EU } & & $\begin{array}{l}\text { Transnational } \\
\text { pressure (4) }\end{array}$ & Supranationalization (3) & \\
\hline & Non-institutional & 1.2 & 9.6 & $N=249$ \\
\hline & Institutional & 12.5 & 30.0 & $N=687$ \\
\hline & All actors & 9.5 & 24.6 & $N=936$ \\
\hline $\begin{array}{l}\text { Notes: Bas } \\
\text { percentage } \\
\text { target }=.23 \\
\text { actors }(N=\end{array}$ & $\begin{array}{l}\text { on both samples, bu } \\
\text { calculated on the tot } \\
* * \text { for all actors ( } N= \\
\text { 87). }\end{array}$ & $\begin{array}{l}\text { tincluding only cases } \\
\text { I. Cramer's } V \text { between } \\
36) ; .32^{* * *} \text { for civil soci }\end{array}$ & $\begin{array}{l}\text { Nith a European issue scope. } \\
\text { scope of the claimant and sco } \\
\text { iety actors }(N=249) ; .18^{* * *} f(\end{array}$ & $\begin{array}{l}\text { Cells show } \\
\text { pe of the } \\
\text { or state }\end{array}$ \\
\hline
\end{tabular}

As for the temporal trends in the types of Europeanization, domestication has remained nearly constant across the years, representing about onethird of claims; externalization and supranationalization have increased slightly in more recent years $(34.5 \%$ and $28.0 \%$, respectively, of cases in 2000 and $30.7 \%$ and $27.4 \%$ in 2002 , compared with a share of about $20-25 \%$ each in 1990 and 1995). Domestication is typical of farmers' protests: the majority of farmers' protests studied between 1992 and 1997 were aimed at national governments and occurred within domestic political spaces, even if they concerned European issues (Bush and Simi, 2001: 102). Comparative research on Spain and the Netherlands has illustrated that farmers have continued to hold their national representatives responsible, even if these have insisted that the causes of the farmers' grievances were beyond their control (Klandermans, 2001). Cases of transnational pressure are stable at about $10 \%$.

Distinguishing the diachronic trends for different types of actor, we can see that for non-institutional actors domestication was more common in the past than in more recent years (moving from about $80 \%$ of cases in the $1990 \mathrm{~s}$ to $45.6 \%$ in 2000 and $54.8 \%$ in 2002). Externalization slowly decreased for institutional actors between 1990 and 2002 (remaining at about 30\%), whereas it increased for non-institutional actors (from 10.0\% in 1990 to $40.8 \%$ in 2000 to $35.2 \%$ in 2002). Transnational pressure is virtually absent for non-institutional actors across the years, and it has remained at a nearly constant level of about 
$12-13 \%$ for institutional actors. Finally, forms of supranationalism increased for institutional actors (from $30.0 \%$ in 1990 to $37.0 \%$ in 2000 and $32.5 \%$ in 2002) but not for civil society.

To conclude, non-institutional actors seem to have more difficulty in allocating resources in order to build European organizational structures. However, even if transnational civil society organizations are still rarely present in the Europeanized public discourse, the tendency to address the EU is not insignificant. The construction of community institutions, as well as the policies chosen by the EU, is increasingly the object of vigorous responses by loose networks of local, national and transnational actors.

\section{Consensual Europeanization or conflictual Europeanization?}

Another relevant dimension to investigate is the degree of conflict in the process of Europeanization. That is, if we find claims concerning Europe, are they supportive or critical of the European polity, politics and policies? The development of territorial politics follows both consensual and conflictual paths. The nation-state evolved through conflicts of greater or lesser degrees of politicization between the centre and the periphery, between the church and the state, with both cleavages contributing to shaping the characteristics of national politics (Rokkan, 1982). The mobilization of other cleavages, in particular social class divides, also contributed to the building of the nationstate, and the struggle to construct a national polity interacted with the production of national policies (Bendix, 1964). Conflicts can (and do) develop around both the very existence of a European polity and the specific policies implemented by European institutions. In this section, we shall investigate some characteristics of consensual versus conflictual forms of Europeanization, comparing institutional and non-institutional actors.

Many studies have indicated a decline in support for the EU in public opinion, stressing the erosion of the 'permissive consensus' based on bureaucratic legitimacy (Eder, 2000: 179-80). Together with the growth of protest targeting the EU (Imig, 2004), the decline of trust in European institutions is an indicator of the weakening of EU legitimacy by 'output' legitimacy secured by the efficacy of policy outcomes, rather than legitimacy secured by representative 'input' procedures (Scharpf, 1999).

Our data confirm a growing dissatisfaction with the functioning of the EU, but also tensions between different images of Europe, supporting the hypothesis that growing competences bring about increasing contestation. In Table 5 we show the distribution of conflictual claims by type of actor, in both 
domestic and 'European' claims-making. ${ }^{8}$ In the operationalization of domestic claims, we consider only those with a national issue scope $(N=$ 1332). Overall, the extent of conflictual claims is lower in European (28.6\%) than in domestic claims-making (36.1\%). Nevertheless, Europeanized conflictual claims have increased, although not linearly, over the years (from $21.2 \%$ of all EU-based claims in 1990 to $34.7 \%$ in 1995, 30.7\% in 2000 and 27.1\% in 2002), whereas the proportion of conflictual claims in the domestic debate remained nearly constant at about one-third of the sample.

We may add that civil society actors (in particular, social movements and parties) are much more conflictual than institutional actors, even in claimsmaking with reference to Europe. Conflictual politics may be more present in national than in European politics, but the degree of conflict in claimsmaking has increased across the years in Europeanized policy fields. Contrary to the expectation that channels for including 'civilized' actors in EU policy-making would tame civil society organizations (see, for instance, Mazey and Richardson, 1993), non-institutional actors are more conflictual than institutional actors even when addressing issues of EU scope, and they do not appear to moderate their repertoire of action. Imig and Tarrow (2001a: 43) also find that, concerning repertoires of EU conflictual politics from 1984 to 1997 , conflictual actions continued to represent a substantial share of claims-making addressing the EU.

In order to delve more deeply into the attitudes of different types of actor,

Table 5 Conflictual claims by actor type in EU-based claims vs. non-EU-based claims: Selected policy fields, 1990, 1995, 2000, 2002

\begin{tabular}{|c|c|c|c|c|c|c|}
\hline \multirow[b]{2}{*}{ Actor type } & \multicolumn{3}{|c|}{ EU-based claims } & \multicolumn{3}{|c|}{ Domestic claims } \\
\hline & $\begin{array}{l}\text { Conflictual } \\
\text { claims (\%) }\end{array}$ & $\begin{array}{l}\text { Total } \\
\text { (\%) }\end{array}$ & $N$ & $\begin{array}{l}\text { Conflictual } \\
\text { claims }\end{array}$ & $\begin{array}{l}\text { Total } \\
\text { (\%) }\end{array}$ & $N$ \\
\hline Institutional & 24.4 & 100.0 & 1236 & 17.3 & 100.0 & 612 \\
\hline Non-institutional & 42.2 & 100.0 & 389 & 52.1 & 100.0 & 720 \\
\hline Parties & 44.8 & 100.0 & 125 & 49.4 & 100.0 & 160 \\
\hline Interest groups & 32.8 & 100.0 & 116 & 37.6 & 100.0 & 101 \\
\hline Movements & 59.0 & 100.0 & 83 & 58.7 & 100.0 & 429 \\
\hline Media & 32.3 & 100.0 & 65 & 20.0 & 100.0 & 30 \\
\hline All actors & 28.6 & 100.0 & 1625 & 36.1 & 100.0 & 1332 \\
\hline
\end{tabular}

Notes: Row percentages are shown. Cramer's $V$ between presence of conflictual claims and actor type (social movements, economic interest groups, parties, media and state actors) $.20^{* * *}$, calculated for EU-based claims; .36*** for domestic claims. 
we can look at our data on the position of claims-makers on the issue of European integration. Are the claims against any deepening of the integration process, or do they imply an extension of the competences of European institutions? Valence position scores on Europe/European integration range in our coding from -1 (against a deepening of the integration process) to +1 (in favour of deepening integration and the extension of the rights and positions of European institutions and regulations; a 0 score indicates claims that are neutral or ambivalent in this respect). In Figure 3, we show the score of the average valence position on Europe for each collective actor, calculated by aggregating the position scores of that actor's claims. ${ }^{9}$ The overall debate in Italy about Europe appears to be characterized by a positive attitude toward Europeanization (+.24), confirming other data about the proEuropean sentiments present in Italian public opinion (della Porta, 2003c: 20-3). In a cross-national comparison with the Europub.com countries, Italy ranks third in support for the process of European integration (after Germany and France) and is followed by Spain, the Netherlands and the UK (Koopmans, 2004: 45).

Institutional actors have more positive attitudes towards European integration, although their support for Europe is not characterized by a linear trend over time. Civil society actors are in general less enthusiastic about the European integration process, with an increase in support for Europe up to 2000, followed by a sharp decrease. Among the non-institutional actors, economic interest groups have a slightly more pro-European position, and social movements and the media are more critical of European integration. In public positions on Europe, then, integration seems to be a project more dear to the political and economic elites than to civil society actors, who,

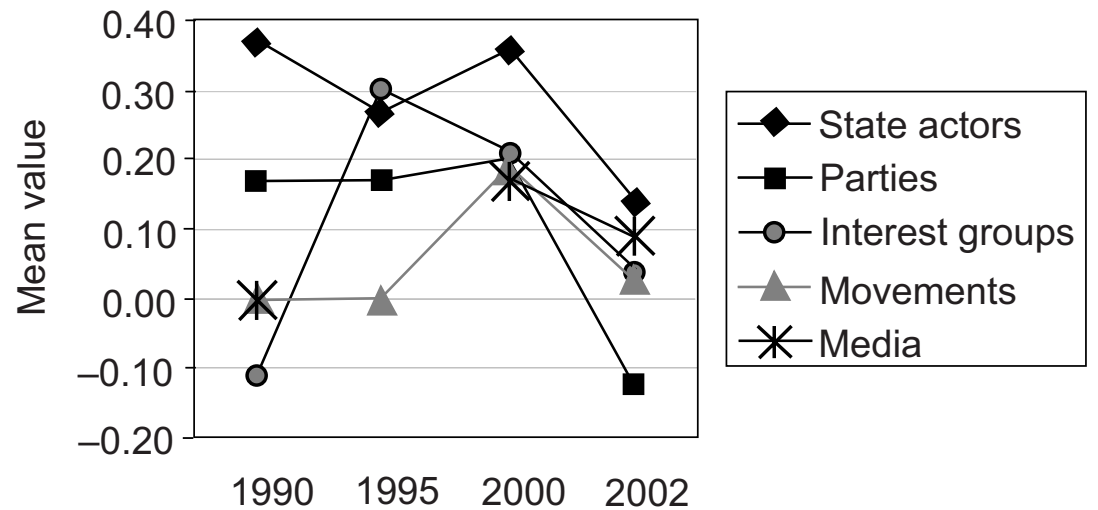

Figure 3 Positions on European integration by actor type (mean values). 
although not homogeneously, feel that they are on the losing side. In crossnational comparison, support for the integration process is everywhere stronger among institutional and party actors ( +.26 across all seven countries) than among various categories of non-institutional actors - economic interest groups (+.12), the media (+.13) and other civil society groups (+.13). The stronger socioeconomic actors (employers and business organizations) are, in most countries, more supportive of the integration process $(+.20)$ than are trade unions (+.12). In Italy, unions emerge as particularly critical of the process in comparison with the more general European trend (-.13; Koopmans, 2004: 43).

However, the support of every type of actor declines after 2000. In Italy, the cross-time analysis shows a decrease in support for Europe from +.30 in 1990 to +.11 in 2002. Once again, this is similar to the general trend emerging in the other European countries covered by the Europub.com project: the average mean for support for Europe of the seven European countries fell from +.39 in 1990 to +.19 in 2002 (Koopmans, 2004: 43).

The general attitudes towards Europe of the different types of actor vary greatly according to the issue under debate. In a cross-issue perspective, civil society claims on European issues that explicitly express a positive attitude to increased Europeanization are at a high level for European integration $(+.16)$ and agriculture (+.18). Education is the policy field where noninstitutional actors mostly express criticism on European integration (-.11). Institutional actors, in contrast, appear more cautious in supporting Europe in claims-making concerning agriculture (+.07) and troop deployment $(0.00)$, as well in debates concerning monetary policy (+.15).

The attitudes of civil society actors towards the European process are also strongly differentiated across policies. Economic interest groups are more critical of Europe when the debate specifically concerns EU integration (-.09) and more favourable when the claims-making concerns pensions (+.29), agriculture $(+0.18)$ or monetary policy $(+.16)$. Social movements, in contrast, express more positive positions regarding Europe in the debate concerning European integration (+.24) than when they talk about pensions $(-1.00)$ or education (-.17)..$^{10}$

Conflict related to the process of European integration is especially high on issues relating to the welfare state and social rights, where the European Union is not considered to have a good track record. These results, which concern much more than the general process of European integration, therefore seem to point to dissatisfaction among non-institutional actors with EU politics, confirming the worry that a lack of 'positive integration' (Scharpf, 1999) is weakening support for Europe among citizens concerned about welfare issues. 
These findings on the conflictual participation of civil society actors may be better interpreted by turning to the qualitative data generated from our interviews. The interview partners were asked about their general perceptions and evaluation of the process of European integration, and how they judged the role and performance of EU institutions in this context ('How do you perceive the process of European integration more generally? What direction is it taking? Do you agree with this development? And how do you see the role and performance of EU institutions in this context?'). The analysis of the attitudes of various national actors towards Europe confirms broad support for European integration, but in terms of very different conceptions of Europe. Europe emerged as an 'imagined community' that meant very different things to different collective actors. In the 1990s, in particular, the European one was part of a multi-level territorial identity compatible with other territorial identities (Fabbrini, 2003: 19). But different actors also tend to construct different Europes. In part, these definitions overlapped with the traditional distinction between Europe as an economic enterprise, based on the pragmatic support of national economies (which appeared to be the view characteristic of many institutional actors), and Europe as a federation based upon a common destiny and common values, with a particular commitment to peaceful interaction (which is the 'model' mentioned most often by noninstitutional interview partners). For example, when considering actors' expectations and normative statements about the future of European integration, institutional actors worried more about instrumental/economic issues (confirming the image of a 'regulatory' Europe), whereas civil society actors focused on the political and social construction of Europe.

From the instrumental point of view, enlargement and the euro are perceived by centre-right institutional actors and interest groups as challenging decisions, especially in a period characterized by economic difficulties (see, for example, interviews 11, 12 and $13^{11}$ ). Enlargement, in particular, is considered to be risky by those who conceive of European integration as mainly legitimized by economic advantages - all the more so for a country that has, until now, enjoyed high levels of EU funding for cohesion policies. In the more Eurosceptic definition, enlargement is 'an acceleration that does not take into account the problems of the assimilation of the member states' (Lega Nord, interview 14).

Most civil society actors focused instead on identity issues - demanding a democratic and social Europe, but criticizing the EU's weakness on both issues. As for the 'democratic deficit', many NGOs stressed the need for a 'bottom-up' process to develop European politics. As the general secretary of the Movimento Federalista Europeo sums it up: 'The EU Council is not good because, from the point of view of constitutional doctrine, it is not a 
democratic institution' (interview 1). Similarly, other social movement organizations complained about the weak powers of the European Parliament vis-à-vis the European Council (see, for instance, interviews 2 and 6), arguing that 'the construction of the European Union comes from the top and there is no low level, except for the movements that attempt to influence 'high politics" (interview 5).

More generally, civil society actors are critical of the direction of European integration, but not on the basis of a traditional 'nationalist' Euroscepticism that defends the nation-state (Marks, 2004). Criticisms are framed using the language of class cleavages rather than territorial ones. Although social movement organizations agree on the importance of a European level of government and citizenship, they stigmatize EU policies as being oriented towards economic success instead of social equality, 'privileging the market over the people'. As the spokesperson for Rete Lilliput, a network of NGOs working on global inequalities, stressed: 'We are favourable to the process of integration but we don't agree with the political direction it is currently taking' (interview 10). The representative of the 'critical' union Cobas (interview 3) confirms this image of the EU as a neo-liberal institution, interested in economic growth but not in social equality: 'I disagree with the direction of the process of integration because it is primarily an economic, a financial one. It is not integration by popular consultation'; a 'Europe that liberalizes more and more the free movement of commodities and dirty money but not persons. It condemns thousands of citizens to death with its restrictive laws on immigration' (interview 4).

To summarize, the need to construct a supranational level of governance is recognized but the weakness of political and social Europe is criticized. This tension between general support for Europe and criticisms of specific EU policies is acknowledged by, amongst others, the leader of the farmers' organization Altragricoltura, who stated:

We are critical of the fact that integration is only a conquest of markets, and that there is no reflection upon what kind of Europe we want. The European Union is the only opportunity we have for imagining a different model of economic development from the American one. We defend this possibility but we don't agree with the reality of the European Union's concrete choices; we are living a contradiction. (Interview 8)

Our interviews with various types of non-institutional actors indicated, however, that although civil society organizations are more critical than institutional actors (in terms of their position on increasing European integration), such organizations (including social movements) have very high levels of interest in the development of European policies and consider the EU level 
to be very important for the present as well as for the future. Social movements express the least support for the European Union, but they show a higher level of interest in it than political parties do; they share a fairly strong belief in the relevance of the European policy level, and an even stronger confidence in its future influence.

\section{The Europeanization of public discourse and civil society: Some conclusions}

Our data indicate that, at least when looking at Italy, there is a certain degree of Europeanization of public discourse in terms of the presence of European claimants, targets and framings of issues, but that this process has specific characteristics. It is selective, insofar as it involves some policy areas but not others; it is mainly top-down, in the sense that non-institutional actors are less present than institutional ones in public debates on Europeanized issues; and it is increasingly contested, in Italy not so much in terms of opposition to a European polity (i.e. to the building of new geographical borders), but more on the basis of specific European policies (in particular, the weakness of social policies) and European politics ( the 'democratic deficit' is linked not only to the weakness of the elective EU body, the Parliament, but also to the lack of transparency of European integration processes) (della Porta et al., 2003; della Porta and Caiani, 2004; della Porta, 2003b). Other recent studies have found similar results in other countries, indicating a certain general degree of Europeanization (Koopmans, 2004; Trenz and Eder, 2004) accompanied by issue specificity (Seidendorf, 2003).

Principally, our results have confirmed that, in terms of political opportunities, multi-level governance is reflected in domestic public discourse. As expected, Europe is more widely discussed in those policy areas where the EU institutions have more competences (especially in monetary policy), but some degree of Europeanization also emerged in policies that remained more within the control of national institutions. Moreover, public discourse on European actors and issues became more and more prominent over time.

Even if European institutions function as an additional level of opportunity, our research confirms that the ability of collective bodies to access supranational levels depends upon their 'regulative, jurisdictional and material resources', and that 'European integration distributed these opportunities of access to extraterritorial resources ... in a differential and unequal way' (Bartolini, 2002: 8; emphasis added). In Italy, although also in other European countries (Koopmans, 2004), acting at the supranational level seems relatively less expensive for actors that are already resource rich at home. In 
Table 6 Position towards Europe by type of actors: Interviews (mean values)

\begin{tabular}{|c|c|c|c|c|c|c|c|c|c|c|c|c|}
\hline \multirow[b]{2}{*}{ Actor type } & \multicolumn{3}{|c|}{ Support for EU } & \multicolumn{3}{|c|}{ Interest in EU policy } & \multicolumn{3}{|c|}{$\begin{array}{l}\text { Importance of the EU } \\
\text { policy (today) }\end{array}$} & \multicolumn{3}{|c|}{$\begin{array}{l}\text { Importance of the EU } \\
\text { policy (future) }\end{array}$} \\
\hline & Mean & $N$ & $\begin{array}{l}\text { Std. } \\
\text { dev. }\end{array}$ & Mean & $N$ & $\begin{array}{l}\text { Std. } \\
\text { dev. }\end{array}$ & Mean & $N$ & $\begin{array}{l}\text { Std. } \\
\text { dev. }\end{array}$ & Mean & $N$ & $\begin{array}{l}\text { Std. } \\
\text { dev. }\end{array}$ \\
\hline Institutional & .88 & 13 & .2 & .96 & 13 & .1 & .67 & 2 & .0 & 1.00 & 5 & .0 \\
\hline Parties & .69 & 13 & .3 & .65 & 12 & .2 & .64 & 11 & .2 & .90 & 10 & .2 \\
\hline Interest groups & .88 & 16 & .2 & .77 & 15 & .2 & .69 & 16 & .3 & .98 & 16 & .1 \\
\hline Movements & .47 & 18 & .4 & .74 & 18 & .3 & .65 & 18 & .2 & .90 & 18 & .2 \\
\hline Total & .72 & 60 & .3 & .78 & 58 & .2 & .66 & 47 & .2 & .94 & 49 & .1 \\
\hline
\end{tabular}


addition, limited references to Europe by non-institutional actors indicate that as a result of an initial focus on the negative aspects of integration - in particular on the free market and economic competition - Europe still does not give much symbolic leverage to actors advocating EU citizenship as including the protection of social rights. The higher level of reliance on institutional sources by journalists covering supranational issues also seems to play a role in limiting the presence of civil society actors in these debates (Bennet et al., 2003). When looking at public discourse, it seems that the processes of Europeanization strengthen those who are already strong nationally, while further marginalizing the weak.

Nevertheless, the growing Europeanization of claims-making by social movements and associations indicates that (although perhaps making a virtue of necessity) civil society actors realize that they cannot remain confined to their own nation-states. If decisions shift to the supranational level, then claims-makers must adapt accordingly and try to reduce their disadvantages in addressing a new level of governance. For resource-poor collective actors in particular, it seems important to combine different territorial levels of intervention by framing concerns in a more European dimension while simultaneously holding on to potential allies in national politics.

The Europeanization of public discourse does not imply increasing consensus on the EU polity or policies. Our data indicate that European integration also involves the interplay of territory and class (or, at least, left-right) cleavages, although not to the same extent as occurred during the construction of the nation-state. The Europeanization process is, in fact, more and more conflictual - including within public discourse. Together with the growth of protests addressing European targets (Imig, 2004), decreasing support for European institutions indicates the failure of output legitimization based upon results rather than input procedures. Long before citizens in France and the Netherlands voted against the European Constitution, opinion polls had signalled a decline in citizen satisfaction with the development of EU institutions, with about half of Europeans dissatisfied (Pache, 2001; Méchet and Pache, 2000), and European institutions are regularly criticized for being 'bureaucratic, inefficient and for lacking transparent procedures' (Le Torrec et al., 2001: 8). The output of the EU seems insufficient, if not negative, to many collective actors. In particular, with reference to the interaction between territorial and social cleavages, our research confirms the presence of a tension between a vision of Europe as promoting a regulated capitalism that addresses social concerns and a neo-liberal vision that is opposed to the expansion of EU competences and instead promotes deregulation (as stressed by Hooghe et al., 2004; Marks, 2004).

Our research suggests that the growing criticism of the EU does not 
necessarily take the form of Euroscepticism. Even if, in Italy, support for European integration tends to remain widespread, there has been a recent increase in contestation of the direction of EU policies, particularly among non-institutional actors. Our research allows us to go beyond the observation of a growing scepticism in order to distinguish the image of Europe around which consensus and/or dissent emerges. The specificity of a 'critical consensus', especially on the Left, can be explained by the characteristics of the European construction process and its inherent tension between instrumental and identitarian images, which prevail, respectively, among civil society and institutional actors. Ever since its beginnings, the EU has in fact been a reaction to the weakening of the European nation-state in certain key areas from the military defence of frontiers to the expansion of markets. As Bartolini puts it, the process of territorial de-differentiation that is at the root of European integration 'finds its initial inspiration in two elements of the new international constellation that followed on from the Second World War. The first was the evidently intolerable cost of historical rivalry between the European states in an era when the destructiveness of war technology had grown out of all proportion to what was at stake in said rivalry. The second was the growing pressure coming from the potential economic marginalization of Europe in the world economy' (Bartolini, 2002: 405). The de-territorialization of defence and the market that was the foundation of the European construction stood, however, in contrast to the maintenance at the national level of decisions over redistribution issues. Even more problematically, where member states have retained their competences on social policies (and in particular, as we have seen, on education and pensions, which are areas strictly related to national integration), monetary policies (and the related 'stability pact') have deprived national governments of some of their main instruments for intervening in matters of social inequality.

To conclude, our research confirms that European integration demands 'a commitment to construct a system, that involves the creation of at least a level of cultural identity and of citizenship able to sustain the principle of social sharing of risks and mechanisms of legitimate political decisions' (Bartolini, 2002: 412). The EU's launching of campaigns on general ethical issues, such as gender equality, anti-racism and human rights (Trenz, 1999), is evidence of the search for a moral basis for a collective identity. Such a moral basis would be equivalent to what the nation represented in the construction of the state. Our research singles out this need and the dissatisfaction with the EU's response to it, which is judged to be hopelessly inadequate. 


\section{Notes}

We wish to thank Claudius Wagemann for his dependable and patient help with statistics, Sara Valenza and Linda Parenti, who collaborated on content analysis and interviewing, Lorenzo Mosca and Massimiliano Andretta, who participated in various steps of the Italian project, the project coordinators Ruud Koopmans and Paul Statham, as well as all other members of all national teams.

1 This article reports results from research carried out in Italy. The research forms part of a larger cross-national project on 'The Transformation of Political Mobilisation and Communication in European Public Spheres' (Europub.com), coordinated by Ruud Koopmans and sponsored by the European Commission in the context of its 5th Framework Programme (HPSECT2000-00046). For an outline, see Koopmans and Statham (2002), available on the project website at http://europub.wz-berlin.de. Integrated reports of the results of the claims-making analysis of the Europub.com project for the United Kingdom, France, Germany, Italy, the Netherlands, Spain and Switzerland, as well as separate reports on each of our seven countries, are available at http:/ / europub.wz-berlin.de/project\%20reports.en.htm.

The Appendix to this article containing the interviews can be found on the EUP webpage.

2 The reliability coefficient for the identification and delimitation of claims was .89. For the variables used in this paper, reliabilities ranged from .85 to 1.00 .

3 In the following analyses we balanced the sample of claims from 1990 and 1995 by assigning them double weight. Furthermore, because only half of the sample (namely 26 days when claims were coded for 1990 and 1995 and 52 when they were coded for 2000 and 2002) contains all the articles found on the selected issues, while in the other half of the sample (again 26 days for historical years, and 52 days for the most recent) only claims with a European scope in at least one of the basic aspects of the claim (actors, addressees, issue) were coded, we based most of our analyses on full sample issues only. By doing this we avoid overrepresenting claims with a European dimension, thus drawing a fair picture of the degree to which 'Europe' is present in the national public sphere. We indicate in the text when the reduced sample is added.

4 In general, as many as $83.5 \%$ (institutional actors) and $92.5 \%$ (non-institutional actors) of all claims on pensions and about $90 \%$ (for both types of actor) of all claims on education have a national, Italian issue scope. Monetary policy claims with a national issue scope account for a share of $9.5 \%$ for institutional actors and $19.6 \%$ for non-institutional actors; claims on agriculture for $18.6 \%$ and $44.4 \%$; claims on immigration for $61.3 \%$ and $83.5 \%$; and claims on troop deployment for $0 \%$ for both types of actors.

5 For parties, claims with a European issue scope remain nearly constant across the years (about 6-7\%), with a significant peak in 1995 (15.6\%).

6 Claims directed to other EU member states slightly decreased for state actors (from $15.0 \%$ in 1990 to $7.4 \%$ in 2002 ), whereas for civil society actors they remained nearly constant at about 3-4\%.

7 For the typology and the related analyses, we considered only claims that have a European issue scope, in order to obtain a data set of claims launched 
in response to the policies or institutions of the EU (EU-based claims). According to this criterion, we selected 1625 'EU-based claims' from a total of 3541 claims.

8 We aggregated action forms into the following broad categories: political decision/executive action, verbal action (e.g. communication events such as press releases) and protest/direct democratic action. We considered as conflictual all those claims in which protest/direct democratic action was used, plus all those accompanied by criticism of their targets. Indeed, calls and appeals for specific targets may be made either in a neutral sense or with expressions of criticism or support for the actors they target. We measured the evaluation of addressees, giving a score of -1 for negative judgements and +1 for support, with 0 for a neutral position.

9 The attitude towards increased European integration (Figure 3) was recorded, for both samples, only for claims that had a European dimension in the issue scope. Position scores were computed only for cells with 5 or more cases. Overall, the mean for all actors during the period under study ( $N$ claims $=$ $1623)$ is $+0.24(+0.30$ in $1990 ;+0.25$ in $1995 ;+0.31$ in $2000 ;+0.11$ in 2002); for institutional actors $+0.28(+0.37$ in $1990 ;+0.27$ in $1995 ;+0.36$ in $2000 ;+0.14$ in 2002), for social movements +0.10 ( 0.00 in 1990 and $1995 ;+0.19$ in 2000; +0.03 in 2002), for economic interest groups $+0.14(-0.11$ in $1990 ;+0.30$ in $1995 ;+0.21$ in 2000; +0.04 in 2002), for parties +0.10 (+0.17 in 1990 and 1995; +0.20 in 2000; -0.12 in 2002), and for the media $+0.13(0.00$ in $1990 ;+0.17$ in $2000 ;+0.09$ in 2002).

10 Parties and the media expressed significant support for Europe only in the debate about European integration (from about +0.15 to +0.17 ); in all the other policy fields they expressed neutral or ambivalent positions.

11 The list of our interview partners can be found in the Appendix.

\section{References}

Bartolini, Stefano (2002) 'Lo stato nazionale e l'integrazione europea: un'agenda di ricerca', Quaderni di Scienza Politica 9(3): 397-414.

Bendix, Reinhard (1964) Nation Building and Citizenship. New York: Wiley.

Bennet, W. Lance, et al. (2003) 'Managing the Public Sphere: Journalistic Construction of the Great Globalization Debate', manuscript.

Börzel, Tanja A. and Thomas Risse (2000) 'When Europe Hits Home: Europeanisation and Domestic Change', European Integration online Papers (EIoP) 4(15), URL (consulted August 2004): http:/ /www.eiop.or.at.

Brinegar, Adam P. and Seth K. Jolly (2005) 'Location, Location, Location. National Contextual Factors and Public Support for European Integration', European Union Politics 6(2): 155-80.

Bush, Evelyn and Pete Simi (2001) 'European Farmers and Their Protests', in Doug Imig and Sidney Tarrow (eds) Contentious Europeans. Protest and Politics in an Emerging Polity, pp. 97-121. Lanham, MD: Rowman \& Littlefield.

Chabanet, Didier (2002) 'Les marches européennes contre le chomage, la précarité et les exclusions', in Richard Balme and Didier Chabanet (eds) L'action collective en Europe, pp. 461-94. Paris: Presses de Sciences Po. 
Della Porta, Donatella (2003a) I new global. Bologna: Il Mulino.

Della Porta, Donatella (2003b) 'The Europeanisation of Protest: A Typology and Some Empirical Evidence', European University Institute, Working Papers.

Della Porta, Donatella (ed.) (2003c) 'Dimensions of Political Opportunities and the Europeanisation of the Public Sphere', Report on Work Package 1, Europub.Com Research Project.

Della Porta, Donatella (2004) 'National Case Report of Delphi Analysis', Report Delphi, Europub.Com Research Project.

Della Porta, Donatella and Manuela Caiani (2004) 'National Case Report on Political Mobilisation and Communication Strategies of Collective Actors', Report on Work Package 5, Europub.Com Research Project.

Della Porta, Donatella and Manuela Caiani (2006) Quale Europa? Europeizzazione, identità e conflitti. Bologna: Il Mulino.

Della Porta, Donatella and Sidney Tarrow (eds) (2004) Transnational Movements and Global Activism. Lanham, MD: Rowman \& Littlefield.

Della Porta, Donatella, Manuela Caiani, Lorenzo Mosca and Sara Valenza (2003) 'Forms of Europeanisation of the Public Sphere in Italy in Cross-time, Crossissue and Cross-media Perspective', paper presented at the Conference on the Europeanisation of the Public Sphere, June, Berlin, Germany.

Diez Medrano, Juan (2003) Framing Europe. Attitudes to European Integration in Germany, Spain and the United Kingdom. Princeton. NJ: Princeton University Press.

Eder, Klaus (2000) 'Zur Transformation nationalstaatlicher Öffentlichkeit in Europa', Berliner Journal für Soziologie 2(10): 167-84.

Fabbrini, Sergio (2003) 'L'europeizzazione: Teorie, comparazioni e implicazioni per l'Italia', in Sergio Fabbrini (ed.) L'europeizzazione dell'Italia, pp. 3-33. Rome: Laterza.

Ferrera, Maurizio (2003) 'Un'Italia salvata dall'Europa, ma ancora libera di danneggiare se stessa', in Sergio Fabbrini (ed.) L'europeizzazione dell'Italia, pp. 243-54. Rome: Laterza.

Franzosi, Roberto (1994) 'From Words to Numbers: A Generalized and Linguistics-Based Coding Procedure for Collecting Event Data from Newspapers', in Clifford Clogg (ed.) Sociological Methodology, pp. 263-98. Oxford: Blackwell.

Gabel, Matthew J. and Simon Hix (2004) 'The Structure of Citizen Attitudes and the European Political Space', in Gary Marks and Marco R. Steenbergen (eds) European Integration and Political Conflict, pp. 13-31. Cambridge: Cambridge University Press.

Gamson, William A. and Andre Modigliani (1989) 'Media Discourse and Public Opinion on Nuclear Power: A Constructionist Approach', American Journal of Sociology 95(1): 1-38.

Gerhards, Juergen (1993) 'Westeuropäische Integration und die Schwierigkeiten der Entstehung einer europäischen Öffentlichkeit', Zeitschrift für Soziologie 22(2): 96-110.

Giugni, Marco and Florence Passy (2002) 'Le champ politique de l'immigration en Europe: Opportunités, mobilisations et héritage de l'Etat national', in Richard Balme, Didier Chabanet and Vincent Wright (eds) L'action collective en Europe, pp. 433-60. Paris: Presses de Sciences Po.

Giuliani, Marco (2000) 'Europeanisation and Italy: A Bottom-up Process?', Southern European Society and Politics 5: 47-72. 
Habermas, Jürgen (1981) Theorie des Kommunikativen Handelns. Frankfurt am Main: Suhrkamp.

Habermas, Jürgen (1991) The Structural Transformation of the Public Sphere. An Inquiry into the Category of Bourgeois Society. Cambridge, MA: MIT.

Hooghe, Liesbet and Gary Marks (1995) 'Birth of a Polity: The Struggle over European Integration', in Herbert Kitschelt, Peter Lange, Gary Marks and John Stephens (eds) The Politics and Political Economy of Advanced Industrial Societies, pp. 70-97. Cambridge: Cambridge University Press.

Hooghe, Liesbet, Gary Marks and Carol J. Wilson (2004) 'Does Left/Right Structure Party Position on European Integration?', in Gary Marks and Marco R. Steenbergen (eds) European Integration and Political Conflict, pp. 120-40. Cambridge: Cambridge University Press.

Imig, Doug (2004) 'Contestation in the Streets: European Protest and the Emerging Euro-politics', in Gary Marks and Marco R. Steenbergen (eds) European Integration and Political Conflict, pp. 216-34. Cambridge: Cambridge University Press.

Imig, Doug and Sidney Tarrow (2001a) 'Mapping the Europeanisation of Contention: Evidence from a Quantitative Data Analysis', in Doug Imig and Sidney Tarrow (eds) Contentious Europeans. Protest and Politics in an Emerging Polity, pp. 27-53. Lanham, MD: Rowman \& Littlefield.

Imig, Doug and Sidney Tarrow (2001b) 'Studying Contention in an Emerging Polity', in Doug Imig and Sidney Tarrow (eds) Contentious Europeans. Protest and Politics in an Emerging Polity, pp. 3-26. Lanham, MD: Rowman \& Littlefield.

Klandermans, Bert, et al. (2001) 'Framing Contention: Dutch and Spanish Farmers Confront the EU', in Doug Imig and Sidney Tarrow (eds) Contentious Europeans. Protest and Politics in an Emerging Polity, pp. 77-95. Lanham, MD: Rowman \& Littlefield.

Knill, Christoph and Dirk Lehmkuhl (1999) 'How Europe Matters. Different Mechanisms of Europeanization', in European Integration online Papers (EIoP) 3(7), URL (consulted August 2004): http:/ / www.eiop.or.at.

Koopmans, Ruud (2002) 'Codebook for the Analysis of Political Mobilisation and Communication in Public Spheres', URL (consulted 05/08/04): http:/ / europub.wz-berlin.

Koopmans, Ruud (ed.) (2004) 'The Transformation of Political Mobilisation and Communication in European Public Spheres. Integrated Report: CrossNational, Cross-Issue, Cross-Time', Report on Work Package 2, Europub.Com Research Project.

Koopmans, Ruud and Jessica Erbe (2002) 'Towards a European Public Sphere? Vertical and Horizontal Dimensions of Europeanised Political Communication', paper presented at the Europub Conference on European Governance and Democracy, 14-15 November, Brussels, Belgium.

Koopmans, Ruud and Paul Statham (1999) 'Political Claims Analysis: Integrating Protest Event and Political Discourse Approaches', Mobilization: An International Journal 4(2): 203-22.

Koopmans, Ruud and Paul Statham (2002) 'The Transformation of Political Mobilization and Communication in European Public Spheres: A Research Outline', Europub.Com Research Project, URL (consulted August 2004): http:/ / europub.wz-berlin.de. 
Le Torrec, Virginie, Philippe Blanchard, Guillaume Garcia and Charles Patou (2001) 'Framing Europe: News Coverage and Legitimacy of the European Union in Five Countries', paper presented at the European Community Studies Association, 31 May-2 June, Madison, WI, USA.

McCarthy, John D., Clark McPhail and Jackie Smith (1996) 'Images of Protest: Estimating Selection Bias in Media Coverage of Washington Demonstrations, 1982-1991', American Sociological Review 61(3): 478-99.

Manin, Bernard (1995) Principes du gouvernement représentatif. Paris: Flammarion.

Marks, Gary (2004) 'Conclusion: European Integration and Political Conflict', in Gary Marks and Marco R. Steenbergen (eds) European Integration and Political Conflict, pp. 235-59. Cambridge: Cambridge University Press.

Mazey, Sonia and John Richardson (eds) (1993) Lobbying in the European Union. Oxford: Oxford University Press.

Méchet, Philippe and Romain Pache (2000) 'L'autre Europe que veulent les Européens', in Dominique Reynié and Bruno Cautrès (eds) L'opinion publique europeénne 2000, pp. 167-80. Paris: Presses de Sciences-Po.

Moravcsik, Andrew (1994) 'Why the European Community Strengthens the State: Domestic Politics and International Cooperation', Working Paper 52, Harvard University.

Pache, Romain (2001) 'L'insatisfaction croissante des opinions publiques européennes', in Dominique Reynié and Bruno Cautrès (eds) L'opinion publique europeénne 2001, pp. 241-8. Paris: Presses de Sciences-Po.

Quaglia, Lucia (2004) 'Italy's Policy towards European Monetary Integration: Bringing Ideas Back in?', Journal of European Public Policy 11(6): 1096-111.

Radaelli, Claudio (2000) 'Whither Europeanisation? Concept Stretching and Substantive Change', European Integration online Papers (EIoP) 4(8), URL (consulted August 2004): http:/ / www.eiop.or.at.

Radaelli, Claudio M. and Fabio Franchino (2004) 'Analysing Political Change in Italy', Journal of European Public Policy 11(6): 941-53.

Risse, Thomas, Maria Green Cowles and James Caporaso (2001) ‘Europeanisation and Domestic Change: Introduction', in Maria Green Cowles, James Caporaso and Thomas Risse (eds) Transforming Europe. Europeanisation and Domestic Change, pp. 1-20. Ithaca, NY: Cornell University Press.

Rokkan, Stein (1982) Cittadini, elezioni, partiti. Bologna: Il Mulino.

Rootes, Christopher A. (2002) 'The Europeanisation of Environmentalism', in Richard Balme, Didier Chabanet and Vincent Wright (eds) L'action collective en Europe, pp. 377-404. Paris: Presses de Sciences Po.

Rucht, Dieter (2002) 'The EU as a Target of Political Mobilization: Is There a Europeanisation of Conflict?', in Richard Balme, Didier Chabanet and Vincent Wright (eds) L'action collective en Europe, pp. 163-94. Paris: Presses de Sciences Po.

Sánchez-Cuenca, Ignacio (2000) 'The Political Basis of Support for European Integration', European Union Politics 1(2): 147-71.

Scharpf, Fritz (1999) Governing in Europe: Effective and Democratic? Oxford: Oxford University Press.

Schmidt, Vivien A. and Claudio M. Radaelli (2004) 'Policy Change and Discourse in Europe: Conceptual and Methodological Issues', West European Politics 27(2): 183-210.

Seidendorf, Stefan (2003) 'Europeanization of National Identity Discourses? 
Comparing French and German Print Media', ECPR Joint Sessions, 28 March 28-2 April, Edinburgh.

Snow, David A., E. Burke Rochford, Steven K. Worden and Robert D. Benford (1986) 'Frame Alignment Processes, Micro Mobilization and Movement Participation', American Sociological Review 51(4): 464-81.

Steenbergen, Marco R. and David J. Scott (2004) 'Contesting Europe? The Salience of European Integration as Party Issue', in Gary Marks and Marco R. Steenbergen (eds) European Integration and Political Conflict, pp. 165-92. Cambridge: Cambridge University Press.

Tarrow, Sidney (1989) Democracy and Disorder. Protest and Politics in Italy 1965-1975. Oxford: Clarendon Press.

Tarrow, Sidney (1994) Power in Movement. Social Movements, Collective Action and Politics. Cambridge: Cambridge University Press.

Thomassen, Jacques J.A., Abdul G. Noury and Erik Voeten (2004) 'Political Competition in the European Parliament: Evidence from Roll Call and Survey Analysis', in Gary Marks and Marco R. Steenbergen (eds) European Integration and Political Conflict, pp. 165-93. Cambridge: Cambridge University Press.

Trenz, Hans-Joerg (1999) 'Anti-Rassismus Kampagnen und Protestmobilisierung in Europa', Forschungsjournal Neue Soziale Bewegungen 12(5): 78-84.

Trenz, Hans-Joerg and Klaus Eder (2004) 'The Democratising Dynamics of a European Public Sphere', European Journal of Social Theory 7(1): 5-25.

Van de Steeg, Marianne (2002) 'Rethinking the Conditions for a Public Sphere in the European Union', European Journal of Social Theory 5(4): 499-519.

Wessels, Bernhard (2004) 'Contestation Potential of Interest Groups in the EU: Emergence, Structure and Political Alliances', in Gary Marks and Marco R. Steenbergen (eds) European Integration and Political Conflict, pp. 195-215. Cambridge: Cambridge University Press.

\section{About the authors}

Donatella della Porta is Professor of Sociology and Director of Studies at the European University Institute, Department of Political and Social Sciences, Badia Fiesolana, Via dei Roccettini, 50016 San Domenico di Fiesole, Florence, Italy.

Fax: +39055 4685201

E-mail: Donatella.dellaporta@iue.it

Manuela Caiani is a PhD student in Political Science at the University of Florence, Department of Sociology and Political Science, Via delle Pandette n. 32, 50127 Florence, Italy.

Fax: +39 0554374426

E-mail: manuela.caiani@iue.it 